\title{
Articulatory Gestures in the Phonoiconic System of Language
}

\author{
Olga I. Brodovich* and Varvara A. Davydova \\ Institute of Foreign Languages \\ 13 Linija 12, Vassilievsky Island, St. Petersburg, \\ 199178, Russia
}

Received 03.11.2017, received in revised form 18.12.2017, accepted 09.01.2018

The article is devoted to the study of that part of the primary-motivated lexicon which is soundsymbolic as opposed to sound-imitative one. This lexis is difficult to identify in dictionaries of modern languages mostly due to historical changes in words' form and meaning. The authors used as the source of their material the words of fictional languages because they can observe processes of primary nomination not complicated by further changes. The findings of the authors revealed presence in their material of the same groups of sound-symbolic words which were shown to exist in natural languages. The analysis conducted in the present article allows suggesting a new subdivision of sound-symbolic lexicon based on the semantic side of the nomination process.

Keywords: phonosemantics, sound symbolism, nomination.

DOI: 10.17516/1997-1370-0200.

Research area: philology, semiotics.

\section{Introduction}

One of the principal aims to be solved by phonosemantics as a special branch of linguistic science is the problem of glottogenesis (Voronin, 1982: 23), the origin of the linguistic sign; to be more precise, the formation of the soundsense link in a word (Voronin, op. cit.: 127). Phonosemantic methods can help reveal the primary link between the material and ideal sides of the linguistic sign.

The object of phonosemantics, the phonoiconic system of language, includes two subsystems - that of sound-imitative signs (onomatopoeia) and of sound-symbolic signs where the denotatum is a non-sound. Of the two, the sphere where the immediate connection between the form and sense of a word is comparatively easy to establish is onomatopoeia, because both the ideal and the material sides of a sign are of one and the same (auditory) sensorial modality. But with sound-symbolic lexicon establishing the sound-sense correlation is much more difficult because the ideal and the material sides of a word belong to different sensorial modalities. Besides, the denotatum in these cases can be any of the non-acoustic phenomena of the inner or outside world of man, which in many cases makes it difficult to identify. It is this

(C) Siberian Federal University. All rights reserved

* Corresponding author E-mail address: olgabrodovich@yandex.ru 
phonoiconic material that we will discuss in the paper.

\section{Theory}

The present research is conducted within the framework of psycholinguistics, which considers both sides of the linguistic sign to be products of psychic processes in man. S. Wilcox spoke of this as of cognitive iconicity (Wilcox 2004). Students of iconicity in language consider that "in all cases the perceived iconicity is not an objective likeness between a referent and a linguistic form but a mentally constructed correspondence between two cognitive products" (Grote, Linz, 2004: 25).

Following I.M. Sechenov's ideas of the 'muscle sense' as the leading factor in the operation of all sensory organs, S.V. Voronin introduced the term kinesthesis (Voronin, 1988), or the motor control system, to designate the 'common denominator' of the sensory system of man and its reflection in the articulatory form of the linguistic sign. This last is thus the product of kinemes, or articulatory gestures.

\section{Research material}

Collecting material for investigation of sound symbolism is no easy matter. Firstly, because, as has been mentioned earlier, the presence of the sound-sense link in this lexicon is much more difficult to prove than in the case of onomatopoeia. Secondly, because all modern languages increase their vocabulary principally through tools of secondary nomination. Examples of primary nomination are extremely rare (Telia, 1990).

Still, modern fiction offers us sets of words built out of new phonetic material, sometimes in quite sizeable quantities. These are texts dealing mostly with non-human characters speaking fictional languages - trolls, gnomes, elves and such-like creatures, humanoids from other planets - or animals. The lexicon of these languages consists of words built specially for the purpose of portraying the characters of the stories and their fictional world.

On the one hand, these languages are, as a rule, made to sound as queer and alien as possible, using sounds and sound combinations impossible in the language of the author. On the other, the author presumably wants his/her reader to more or less understand what is being said. This means that the sound shape of such words is built out of sounds which the author finds compatible with the designations of corresponding ideas.

Note that these fictional languages (sometimes referred to as artlangs) differ from the languages constructed for the purpose of international communication, such as Esperanto, in that the referents of the words are mostly fictional entities. Besides, even in the most developed examples of artlang, such as J.R.R. Tolkien's languages of Middle-earth, the volume of the lexicon is fairly modest compared with that of any natural or quasinatural language. Finally, these languages are constructed with the aim of communication, not so much between the characters, as between the author and the reader. Therefore authors build their nominations basing on the principles and norms of natural languages. Sometimes the authors supply translations of their fictional vocabularies into their own (natural) languages. But even then the sounds they use to build their fictional vocabulary are made to agree with the statistically expected sound-sense correlations proved to exist between phonemes of natural languages and certain types of meanings (Whissell, 1999, 2000). All this makes fictional languages a useful source of primary nominations to investigate.

The total number of accumulated fictional vocabulary even in the literature of one, English, language is fairly big and representative. A useful property of these notations is that they have no history of phonetic changes obscuring the original phonetic shape of a word - something with which 
the researcher constantly has to do in dealing with words of natural languages. Below we will show that although examples represent different artlangs, there is much that is common to all of them, including the sound-sense correlation.

The source of the material collected were dictionaries of the by now well-known fictional languages: those of Middle-earth by J.R.R. Tolkien, the Na'vi language of Paul Frommer, the Klingon language of Mark Okrand and finally of the somewhat lesser known Lapin, the rabbit language in R. Adams' Wateship Down (Adams, 2005; Fauskanger, 2013; Klingon Linguistic Academy, 2017; Miller, 2017; Okrand, 1992).

All the above authors wrote in English. Therefore it were words of English that were used for comparison with the fictional lexicon. As the source of the English words with the proven sound-sense correlation we used the Dictionary of English Phonoiconic Words in Diachronic Perspective by M.A. Flaxman (Flaxman, 2016).

\section{The results of the investigation}

In his pioneering work Fundamentals of phonosemantics (Voronin op.cit.) S.V. Voronin subdivided the sphere of non-acoustic denotata into two subspheres, depending on whether they belong to the inner or outer world of man. The corresponding articulatory gestures are either intra- or extrakinemes (Voronin, op. cit:: 71-73).

This subdivision reflects the difference in perception and articulatory imitation of the processes and objects of man's internal and external world, thus forming two classes of sound-symbolic vocabulary, viz. intra- and extrakinesemisms.

\section{Intrakinesemisms}

This class of words denotes phenomena occurring within the human body. The denotata in these cases are reflex movements, such as coughing, sneezing, sucking, swallowing, emotionally caused movements as laughter, the mimic of disgust or fright, etc. These denotata may or may not have a sound produced by the corresponding muscle movement, but in these cases the sound is secondary with respect to the reflex movement causing it.

Take for example pejoratives. The reflex movement in these cases often consists either of downward movement of mouth corners or of the imitation of retching, with glottal muscles constricted and/or the tongue coming out. In terms of articulation, it shows through using back vowels, often labialized, and labial or velar/ glottal consonants.

In English there is a big number of intrakinesemisms:

Pejoratives: gaff, geck, goofy, gook, grudge, grumble, gump, hooey, etc. - all with velar consonants and mostly with low back vowels.

Yawning: gap, gape (>Indeurop. *ghai'yawn') - a velar consonant combined with a low vowel to imitate straining of the glottal muscles.

Swallowing: glug, gobble, gullet, gulp, guzzle, chugalug - velar consonants combined with back vowels.

Kissing: buss, kiss (>Commn. Germ. *kuss), smooch, mwah - the participation of the mouth is reflected in the use of labial consonants and labialized vowels.

Participation of the nose in certain processes is reflected through using nasals. Thus sneeze, snore, snuff, etc.

Our material includes many examples of intrakinesemisms. Thus,

$\boldsymbol{v} \ddot{\boldsymbol{a}}$ ' [væ?] adj. unpleasant to the senses (Na'vi); vair [veə] v. to excrete, to pass poop (Lapine); tsewtx [tscut'] adj. dirty (Na'vi).

See some other examples of intrakinesemisms from our material.

hahaw ['ha.hau] v. sleep (Na'vi) - pharyngeal spirants in reduplication to imitate rhythmical breathing; 
hob [xob] v. yawn (Klingon) - velar spirant and a back vowel to imitate the spasmodic movement of the glottis in yawning;

kxukx [k'uk'] v. swallow (Na'vi);

ghup [уuр $\left.{ }^{\mathrm{h}}\right]$ v. swallow (Klingon);

hugh [xuy] n. throat (Klingon);

ghagh [yay] v. gargle (Klingon) - all these connected with processes occurring in the throat, which is reflected in the use of velar consonants and back vowels.

Meanings connected with the nose and nasal cavity are expressed through using nasals. Thus, ontu ['on.tu] n. nose (Na'vi);

thon [ $\left.\mathrm{t}^{\mathrm{h} l} \mathrm{lon}\right] \mathrm{n}$. nostril (Klingon).

Some of the intrakinesemisms are built through demonstrating the mimic of facial muscles. See for example

pom [pom] n. kiss (Na'vi) - lips prepared for the act of kissing;

$\boldsymbol{k} \boldsymbol{x} \boldsymbol{a}[\mathrm{k}$ 'a] n. mouth (Na'vi) - the most open vowel demonstrating an open mouth;

$\boldsymbol{w} \boldsymbol{S} \boldsymbol{S}$ [wus] n. lip (Klingon) - using labials to denote the corresponding meaning.

In certain cases kinesemisms are not direct designations but rather approximations, as in He'So' [хз?.so?] v. stink (Klingon), where the emotion of disgust is rendered through the articulation of the glottal stop (constriction of the glottis) and not through any reflection of the movement of facial muscles. See also burgh [bury] n. stomach (Klingon), where the organ is designated through imitation of the sound it makes. Interestingly, in the same language there is an onomatope bor [bor] v. gurgle (Klingon) of which the author says: this specifically refers to the sound that a stomach makes (Klingon Linguistic Academy 2017, s.v. bor).

One of the laws of phonosemantics, The Multiple-Choice Nomination Law (Voronin, 2005: 70-73), declares, inter alia, that one and the same motif of nomination can have more than one form of representation, using different modes of articulation.
In our material there are lexemes demonstrating this fact. Take for example nominations of laughter. Laughter as a physiological phenomenon which consists in the reflex spasmodic movement of the diaphragm resulting in a series of sharp exhalations. These last are combined with the working of the speech organs, with the air flow going in two different ways.

1. In most cases it goes through the glottis with the mouth open. Therefore laughter is imitated using sounds articulated deep in the mouth cavity: velars or glottalized consonants, as in

$$
\begin{aligned}
& \text { hagh }[\mathrm{xay}] \mathrm{v} \text {. laugh (Klingon); } \\
& \text { hangham ['hay.ham] v. laugh (Na'vi); }
\end{aligned}
$$$$
\text { hiyik ['hi.jik] adj. funny, strange (Na'vi). }
$$

Compare English examples of giggle or laugh $(<$ ProtoGerm*hlahhian).

2. Sometimes, however, laughter may be realized with the mouth closed. In these cases there will be an expiratory element combined with the labials. Thus

'ipu ['Pi.pu] adj. humorous, funny, amusing (Na'vi).

Compare English examples of guff, boff, scoff.

An overview of the data shown above makes us to conclude that the relations of an intrakinesemism with its denotatum is based on metonymy, as it is always a choice of a part to represent the whole. It is especially clear in the cases of non-verbal nominations like tsewtx [tscut'] adj. dirty, hugh [xuy] n. throat, $\boldsymbol{k x \boldsymbol { a }}$ [k'a] n. mouth, hiyik ['hi.jık] adj. funny, strange - and the like.

\section{Extrakinesemisms}

Among the best-known and well-accepted cases of sound symbolism of the extrakinemic type are designations of big versus small objects shown through the opposition of low and high vowels. Our material gives quite a number of such examples. See, for instance, 
nominations of big objects:

balar [balar] the great bay (Elvish);

hawng [haun] n. overabundance (Na'vi);

hoet [ho.et] adj. vast, broad, expansive (Na'vi);

tsawl [tsaul] adj. big (in size), tall (Na'vi);

sloa [slo.a] adj. wide (Na'vi);

Sach [sat] ] v. expand (Klingon).

nominations of small objects:

'it [?it] n. bit, a small amount (Na'vi);

$\boldsymbol{h i} \boldsymbol{i}$ [hr.Pi] adj. small, little (in size) (Na'vi);

lini [1.nI] $\mathrm{n}$. young of an animal, bird, fish, insect

(Na'vi);

rina' [ri.na?] n. seed (Na'vi);

$\boldsymbol{t} \boldsymbol{I r}\left[\mathrm{t}^{\mathrm{h}} \mathrm{Ir}\right] \mathrm{n}$. grain (Klingon);

ilva [Il.va] n. flake, drop, chip (Na'vi);

tìm [tIm] adj. low (Na'vi);

$\boldsymbol{t} \boldsymbol{I S}$ [ $\left.{ }^{\mathrm{h}}{ }^{\mathrm{IS}}\right] \mathrm{v}$. be light (weight) (Klingon);

-tsyìp [-tsjıp] diminutive suffix (Na'vi);

aew, aiwe [aiw, aiwe] n. small bird (Tolkien, Elvish).

Besides the opposition of $\mathrm{big} /$ small there is in our material a group of lexemes demonstrating the opposition of narrow/broad objects. This opposition is achieved through using obstructions for the air flow through the mouth thus narrowing the opening of the mouth - for designations of narrow objects. There are two different foci of this narrowing

1. alveolar narrowing, as in snep [snep] adj. narrow (Na'vi); snew [sneu] v. constrict, tighten (Na'vi);

lang [lay] v. be thin (Klingon)

and 2. palatal narrowing, as in

'ekxin: [?ع.k'in] adj. tight (Na'vi);

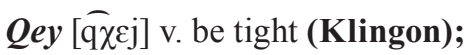

ekxan [ع.k'an] n. barricade, obstruction (Na'vi).

The phonoiconic lexicon with the meaning of something broad is constructed of phonemes whose articulation does not preclude the free flow of air through the mouth cavity. It is mostly performed by low vowels, sonorants and spirants. Thus um [um] adj. loose (Na'vi);

hoet [ho.et] adj. vast, broad, expansive (Na'vi);

sloa [slo.a] adj. wide (Na'vi);

Sach [satf] v. expand (Klingon).

Another well-known group of

extrakinesemisms is formed by the nominations of round objects achieved through the use of labials and labialized phonemes. The rounding or protrusion of lips with the ensuing increase in the volume of the mouth cavity are direct indications of the rounded shape of the objects nominated. Thus

koum [ko.um] adj. rounded, curved (Na'vi);

ko'on [ko.?on] n. ring, oval, closed shape roughly circular (Na'vi);

ropx [rop'] n. hole (going clear through an object) (Na'vi);

pxaw [p'au] adp. around (Na'vi);

gho [४о] n. circle (Klingon);

$\boldsymbol{b a v}$ [bav] v. orbit (Klingon);

rum [rum] n. ball (Na'vi);

loi [lo.i] n. egg (Na'vi);

srok [srok] n. bead (decorative) (Na'vi);

rond [rond] $\mathrm{n}$. vaulted or arched roof, or a large hall or chamber so roofed (Elvish);

$\boldsymbol{m o Q}[\operatorname{moq} \chi]$ n. sphere (Klingon).

Compare this with some of English designations of rounded objects: blob, bubble, bud, cob, cup, goggle, hump, knob, lobe, orb, papule, poop, pot, pumpkin, tub.

The following group of extrakinesemisms is composed of designation of strain. The group of sound-symbolic words with the common meaning of strain was first singled out by S.V. Voronin (Voronin, 1982: 103-107), who showed that a denotatum of strain can be imitated through straining the muscles of the speech organs. In our material there are two subgroups here, namely designations of compression and of exertion:

\section{compression}

The sense of squeezing is imitated through the use of the nasal velar $/ \mathrm{y} /$ whose articulation 
includes the velar occlusion sensed as a pressure of the tongue base on the palate. Thus

thong [ $\theta$ oy] n. oppression (Elvish); sanga [saya] n. press, crowd, throng (Elvish).

\section{exertion}

Our material demonstrates a link between designations of exertion and velar consonants. The existence of such link in natural languages was first noted even in the early work by John Wallis (Wallis, 1674: 49) who connected the sound combinations /sk-, skr-/ with the meaning of strong pressure. The sound-symbolic potential of the velar $/ \mathrm{k}$ / was noted by other linguists (see Egorova, 2008: 19; Magnus, 1998). The energetic occlusion occurring in the articulation of velars and the exertion necessary for breaking it can symbolically represent sensations connected with different situations of exertion in the outside world of man.

See, for example, lexemes with the general meaning of aggressive actions in our material.

'eko [?c.ko] v. attack (Na'vi);

ska'a [ska.Pa] v. destroy (Na'vi);

ndak [ndak] n. battle (Elvish);

kx ll [k'l:] n. charge, running attack (Na'vi);

pxek [p'ck] v. kick, shove (Na'vi);

takuk [ta.kuk] v. strike, hit one's target (Na'vi).

Another example is served by words with the general meaning of active movement (including that of a water flow):

alak [alak] adj. rushing (Elvish);

Ascar [askar] "rushing, impetuous" - a name of a river (Elvish);

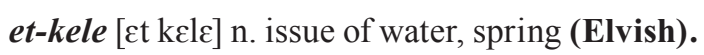
See also words describing muscular activity:

girith [gIrI $\theta$ ] n. shuddering (Elvish);

rikx [rrk'] vin. move, shift position (Na'vi);

walak [wa.lak] adj. energetic, active (Na'vi);

and those connected with the actions of a hand:

cam $[\mathrm{kam}] \mathrm{n}$. hand held cupped in the attitude of receiving or holding (Elvish);

tsyokx [tsjok'] n. hand (Na'vi); $r u Q[$ ruq $\chi$ ] v. control manually, by hand (Klingon);

or those designating bending of objects

$\boldsymbol{c u}[\mathrm{ku}] \mathrm{n}$. bow (Elvish)

tsko [tsko] n. bow (weapon) (Na'vi);

lok [lok] bend, loop (Elvish).

When, as opposed to these situations, a smooth movement is designated, it is done through using the lateral $/ 1 /$. The sound-symbolic meaning of /1/ and /sl/ for designations of smooth objects and/or smooth movement was marked in the earliest publications touching on phonoiconicity (Wallis, op. cit.). Here are some examples from our material:

slayk $\mathrm{v}$. brush, comb (Na'vi);

slele ['sle.le] v. swim (Na'vi);

sloan [slo.'an] v. pour (Na'vi);

lìng [lin] v. float in the air, hover (Na'vi).

A closer analysis of the examples demonstrated above makes us conclude that the mechanism of the approximation of extrakinemes with their denotatum is radically different from that of intrakinemes. Describing extrakinemes as mimic imitations of processes and forms of the outer world of man, S. Voronin (Voronin 1982: 76) showed that in these cases human speech sounds reflect respective images not in their totality but through their properties chosen as key ones, like the shape of an object, its size or type of the characteristic movement. The basis of approximation of the denotatum with its imitation through a speech gesture is the likeness or similarity between a property of the object and a property of the speech gesture and the resulting sound. This similarity makes the relation discussed metaphoric.

\section{Conclusion}

At the present moment the study of soundsymbolic lexicon has to its credit the demonstration of groups of words with the proven sound-sense link without, however, providing any basis for 
their semantic classification. The subdivision into intra- and extrakinesemisms is, of course, a great achievement, but it touches upon the mechanism of nomination and leaves the semantic side unattended to. The same subdivision of this lexicon, but in this case based on semantic processes in nomination gives us another grouping of soundsymbolic words: those based on metonymy against metaphorically constructed words. This suggests yet another angle of subdivision of this vocabulary, namely their subdivision into signs-gestures and signs-indications.

\section{References}

Adams, R. (2005). Watership Down. New York, Scribner, 496 p.

Egorova, A.A. (2008). Zvukoizobrazitelnost' $v$ traditsionnoi angliiskoi detskoi poezii (na materiale Nursery Rhymes) avtoref. dis....kand. filologicheskikh nauk [Sound Symbolism in the Traditional English Children's Poetry (on the material of Nursery Rhymes)]. Cand. Diss. Phil. Abstract. Moscow, 24 p.

Fauskanger, H.K. (2013). Quettaparma Quenyallo [Quenya-English Wordlist]. Available at: http:// www.folk.uib.no/hnohf/wordlists.htm (accessed 30 October 2017).

Flaxman, M.A. (2016). Slovar angliiskoi zvukoizobrazitelnoi leksiki v diakhronicheskom osveshchenii [Dictionary of English Phonoiconic Lexicon in Diachronic Perspective]. St. Petersburg, Izdatel'stvo Russkoi Khristianskoi gumanitarnoi akademii, 204 p.

Grote, K., Linz, E. (2003). The Influence of Sign Language Iconicity on Semantic Conceptualization, In From Sign to Signing: Iconicity in Language and Literature 3, ed. W.G. Müller, O. Fischer. Amsterdam, Philadelphia, John Benjamins, 23-40.

Magnus, M. (1998). The Meanings of Phonetic Features. Available at: http://www.trismegistos. com/MagicalLetterPage/Consonants.html (accessed 30 October 2017).

Miller, M. (2017). Na'vi - English Dictionary. Available at: https:/eanaeltu.learnnavi.org/dicts/ NaviDictionary.pdf (accessed 30 October 2017).

Klingon Linguistic Academy (2017). New Klingon Words. Available at: http://www.kli.org/aboutklingon/new-klingon-words/b/ (accessed 30 October 2017).

Okrand, M. (1992). The Klingon Dictionary (2nd edition). New York, Pocket Books, 191 p.

Telia, V.N. (1990). Nominatsiia [Nomination], In Lingvisticheskii entsiklopedicheskii slovar [Encyclopedic Dictionary of Linguistics], ed. V.N. Iartseva. Moscow, Sovetskaya Entsiklopediia, 682 p.

Tolkien, Chr. (1977). Appendix: Elements in Quenya and Sindarin Names, In The Silmarillion, ed. Chr. Tolkien. London, George Allen \& Unwin, 315-365.

Voronin, S.V. (2005). Challenging an Enigma: The Basis of Sound Symbolism, In Iconicity. Glottogenesis. Semiosis (Sundry Papers). St. Petersburg, St. Petersburg State University, 50-56.

Voronin, S.V. (1982). Osnovy fonosemantiki [Fundamentals of Phonosemantics]. Liningrad University Press; 2nd edition. Moscow, LENAND, 2006, 248 p.

Wallis, J. (1674). Grammatica linguae anglicanae. Oxoniae: Typis L. Lichfield ... et prostant venales apud Joh. Crosley, $190 \mathrm{p}$.

Whissell, C. (2000). Phonoemotional Profiling: a Description of the Emotional Flavour of English Texts on the Basis of the Phonemes Employed in Them, In Perceptual and Motor Skills, 91, 617-648.

Whissell, C. (1999). Phonosymbolism and the Emotional Nature of Sounds: Evidence of the Preferential Use of Particular Phonemes in Texts of Differing Emotional Tone, In Perceptual and Motor Skills, 89, 19-48. 
Wilcox, S. (2004). Cognitive Iconicity: Conceptual Spaces, Meaning, and Gesture in Signed Languages, In Cognitive Linguistics, 15(2), 119-147.

\title{
Речевые жесты в звукоизобразительной системе языка
}

\author{
О.И. Бродович, В.А. Давыдова \\ Санкт-Петербургский институт \\ иностранных языков \\ Россия, 199178, Санкт-Петербург, \\ Васильевский остров, 12-я линия, 13
}

Статья посвящена исследованию звукосимволической примарно мотивированной лексики, которая наряду со звукоподражательной составляет звукоизобразительную систему языка. Данную лексику сложно обнаружить в словарях современных языков, так как в ходе исторического развития форма и значение слова подвержены изменениям. Выбор лексики вымышленных языков в качестве источника материала для исследования позволяет наблюдать процессы примарной номинации, не осложненные дальнейшими изменениями. Авторы обнаружили в вымышленных языках группы звукосимволических слов, ранее выявленные в естественных языках. Проведенный в статье анализ позволяет по-новому взглянуть на типологическое деление звукосимволических слов на основании семантического аспекта процесса номинации.

Ключевые слова: фоносемантика, звукосимволизм, номинация.

Научная специальность: 10.00.00 - филологические науки, семиотика. 